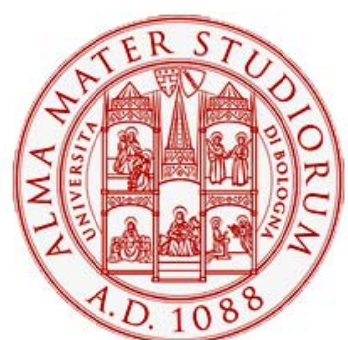

Alma Mater Studiorum - Università di Bologna DEPARTMENT OF ECONOMICS

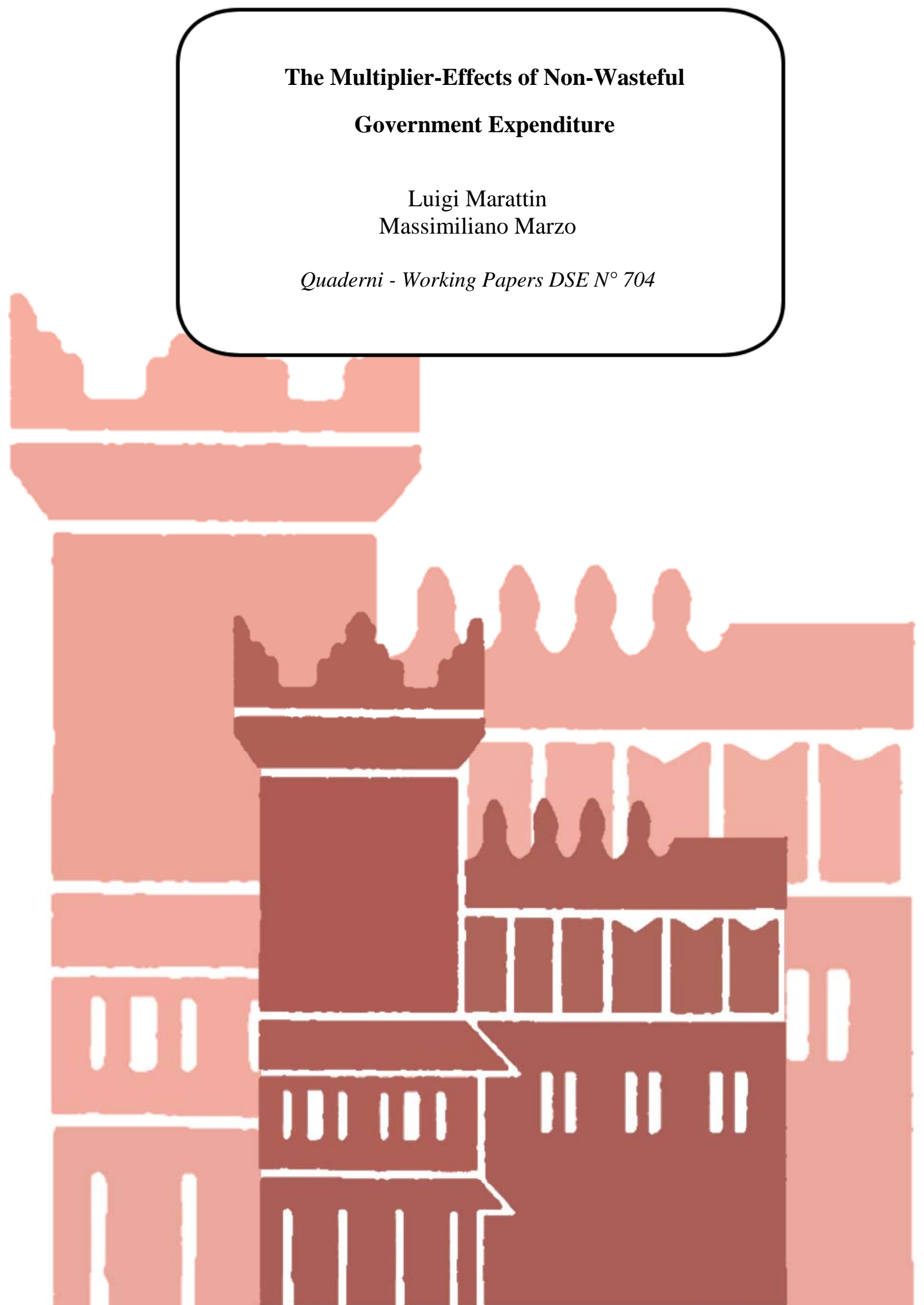




\title{
The Multiplier-Effects of Non-Wasteful Government Expenditure*
}

\author{
Luigi Marattin ${ }^{\dagger}$ \\ Massimiliano Marzo \\ University of Bologna \\ University of Bologna
}

June 2010

\begin{abstract}
Macroeconomic literature has traditionally regarded public expenditure as yielding no utility per se to any agent in the economy. In line with a few previous contributions (Linneman and Schabert 2004, Bouakez and Rebei 2007) in this paper, we build a New Keynesian DSGE model with real and nominal rigidities and distortionary fiscal policy rules, calibrated on the Euro-area (1990:1-2008:4), where part of public spending is allowed to either Edgeworth complement or substitute private consumption by affecting its marginal utility. We show that the the interaction between the share of usefulness of public spending and the specification of fiscal and monetary policy rules is able to deliver private consumption multipliers which are in line with the empirical findings for the Euro-Area.
\end{abstract}

JEL Classification: E62, E63

Keywords: Fiscal Policy, Useful Government Expenditure, Fiscal Multipliers.

\footnotetext{
${ }^{*}$ We are grateful to Lunch Seminar participants at the Department of Economics, University of Bologna for many useful comments and advices. Special thanks go to Emanuele Bacchiega for special advices. The usual disclaimer applies.

†Corresponding author: Department of Economics, University of Bologna. 45, Strada Maggiore, 40125 Bologna, Italy. Phone: ++39-051-2092606, email: luigi.marattin@unibo.it
} 


\section{Introduction}

How does the standard analysis on fiscal policy multipliers change when government spending directly affects private consumption? In this paper we evaluate the ability of DSGE models to generate positive consumption multipliers in line with those found by empirical analysis on the Euro-zone. The hypothesis we made is that public expenditure flow - financed by distortionary taxation Edgeworth complements or substitutes private consumption by directly affecting its marginal utility. We present a simple DSGE model able to account for the positive effects on consumption following a government expenditure shock without the role of credit constrained agents, as described in Galì et al. (2007). Our model shows that with a proper definition of the degree of complementarity between consumption and public expenditure, and by explicitly considering distortionary taxation as mean of financing, we obtain fiscal policy multipliers in line with empirical evidence for the Euro area. This shows a more general and less 'ad hoc' framework to shed light on the fiscal policy transmission mechanism.

Following the debate on the implementation of the 2009 massive fiscal stimulus plan, there has recently been a renowed interest on the size of government spending multipliers. In an official document of the US administration attempting to assess the employment impact of the American Recovery and Reinvestment Plan, Romer and Bernstein (2009) declare a GDP multiplier of public expenditure equal to 1.24 after two quarters, and 1.44 after a year for the US economy. That kind of magnitude seemed greatly optimistic under the light of existing econometric evidence. ${ }^{1}$ Galì et al (2007) report an overview of estimated short-run multipliers generated by Structural Vector AutoRegressive (SVAR) models: although they do not seem to be stable across time, they show fiscal multipliers vary between 0.5 and 1 one year after the impact (a range confirmed by Hall 2009). Nevertheless, the debate on the output multiplier of a government spending shock is "merely" quantitative; theoretical models ${ }^{2}$ along with empirical analysis and policy notes all agree on the (positive) sign of the output multiplier, even though they disagree considerably on its magnitude.

The government expenditure multiplier on private consumption constitutes an even more controversial issue, as the disagreement regards both magnitude and sign. Standard neoclassical models predict a decrease in private consumption after a positive government spending shock, as the result of negative wealth effect inducing a decrease in normal goods demand (consumption and leisure). A lower consumption demand generates a negative consumption multiplier, while a lower leisure demand shifts out labor supply schedule, thereby reducing real wage and increasing output. In contrast with such theoretical predictions, a great deal of empirical evidence (see Perotti 2007 for a cohmprensive review) reports the existence of a positive consumption multiplier, along with the usual

\footnotetext{
${ }^{1}$ Among the many contributions, Blanchard and Perotti 2002, Ramey and Shapiro 1997, Romer and Romer 2007, Ramey 2008, Mountford and Uhlig 2008.

${ }^{2}$ Baxter and King (1993), Barro and King (1994).
} 
debate on magnitudes. Efforts aimed at reconciling such evidence with theoretical modelling has followed two broad approaches, whose dividing line is the use of nominal rigidities.

The first approach includes theoretical frameworks firmly grounded in the flexible price Real Business Cycle tradition. Particularly, one direction explores non-walrasian labor market (Shimer 2005, Hall 2009), and shows that a more realistic modelling of labor's demand and supply can lead to non-negative consumption multipliers (along with an output multiplier close to 2). A second set of contributions inserts complementarity between labor effort and private consumption in the utility function, in order to overcome the decrease in aggregate demand for private consumption emerging from negative wealth effect (Linneman 2006, Hall and Milgrom 2008). However, Bilbie (2009) demonstrated that complementarity between consumption and labor implies a negative sloped labor supply curve and that aggregate consumption is an inferior good.

The second approach explicitly considers the presence of nominal rigidities, who however are not sufficient per se to generate positive consumption multiplier. Under price stickiness, in fact, business cycle fluctuations are demanddriven; therefore a government spending's exogenous shock raises labor demand and - if this movement outweights the labor supply shift triggered by the negative wealth effect - the public spending shock results in a real wage increase. This is the starting point to obtain a positive effect on private consumption: in order to achieve it, the literature has so far employed two alternative approaches. The first one adopts non-standard utility function specifications in order to strenghten the substitution effect after the increase in real wage (which substitutes leisure with consumption) at the expenses of the negative income effect behind the labor supply movement. Ravn et al (2007) use deep habits into the utility function, Perotti and Monacelli (2008) employ the preferences specifications pioneered by Greenwood,Hercowitz and Huffman (1988) - the so-called GHH preferences - so to minimize the labor supply shift after the government spending shock. The second mechanism based on price rigidity is the well know credit-constrained agents approach (Galì et al 2007, Lopez-Salido and Rabal 2006, Coenen and Straub 2005), where a fraction of consumers is not allowed to optimize over the life cycle and is therefore forced to consume exclusively out of their current income (that's why the increase in real wage is a necessary condition). However, a widely recognized drawback of this approach is the excessive reliance on the exogenous fraction of credit-constrained agents in order to obtain a non-negative consumption multiplier; moreover, often the required share of liquidity constrained agents is close to half of the total population.

In this paper, we consider an alternative approach focusing on the presence of a non-wasteful flow of government expenditure able to per se affect private consumption through modifications of its marginal utility. Our motivation is based on the belief that the usual assumption of public expenditure's total wastefulness is less justifiable as we observe the implementation of massive recovery plans after the 2009 recession $^{3}$. There have been attempts to explic-

\footnotetext{
${ }^{3}$ Few papers (Aschauer 1985, Karras 1994, Ni 1995, Amano and Wirjanto 1998, Okubo
} 
itly consider Edgeworth complementarity/substitutability between private and public consumption into DSGE models. Linnemann and Schabert (2004) use a New Keynesian framework with sticky prices and formally derive the parametric conditions under which government expenditure complements private consumption. By contrast, Bouakez and Rebei (2007) employ a standard RBC model, augmented with habit formation to improve the empirical fit, and estimate the parameters using U.S.data, finding a strong degree of complementarity between public and private consumption ${ }^{4}$.

Our paper builds on those two contributions, by extending their analysis in three directions: first, we employ a fully-fledged New Keynesian general equilibrium model calibrated on the Euro-area with real and nominal rigidities, monetary policy and fiscal rules with distortionary tax rates targeting the stock of government debt. Second, we do not limit ourselves to the derivation of the parametric conditions for complementarity/substitutability, but rather explore the general equilibrium effects particularly regarding government spending multipliers on output and consumption. Third, we explicitly investigate the relationship between multipliers' magnitude and the specification of fiscal and monetary policy rules.

Our main results show can be summarized as follows.

First, the ability of the model to generate positive consumption multipliers under Edgeworth complementarity is preserved after the introduction of distortionary fiscal rules; indeed, a more aggressive stabilization stance on the fiscal side reduces multipliers'magnitudes.

Second, conditioning on the presence of at least half of useful government spending, monetary policy does not need to be trapped into zero nominal interest rate lower bound for the output multiplier to be large; all is needed is a zero output response, as the public spending shock is no longer completely inflationary. Analogously, such a situation delivers a positive and empirically plausible consumption multipliers, in line with the econometric evidence presented in the paper.

The remainder of this paper is organized as follows. Section 2 recalls empirical evidence for the Euro-area recently collected by Marattin and Salotti (2010). Then, we move to the model aims at explaining it: section 3 outlines our baseline theoretical framework, section 4 defines equilibrium and calibrates the model on EU economy (1990-2008), section 5 presents our results. In section 6 , we test the basic intuition on multipliers' sizes by comparing different varieties of our theoretical framework. Finally, concluding remarks are contained in section 7 .

2003) tried to estimate the degree of substitutability between private consumption and public spending, with largely mixed and inconclusive evidence. Fiorito and Kollinztas (2004) linked the analysis on the distinction between public expenditure on "merit" goods Vs "public" goods in 12 EU countries.

${ }^{4}$ Leeper et al (2009) consider the impact of productive government investment, rather than consumption, under alternative sources of fiscal financing. They find that the expansionary effect of public investment is maximized when it is financed by reducing lump-sum transfers, and minimized when using the tax rate on capital income. 


\section{An empirical perspective on the EU area}

Most of the empirical literature on the effects of government expenditure on private consumption is based on US economy (among others, Fatas and Mihov 2001,Blanchard and Perotti 2002,Galì and Perotti 2003,Ramey 2007,Monacelli and Perotti 2008). Marattin and Salotti (2010) use data on 14 Euro member states (1970:2006) and estimate the following structural Panel VAR model:

$$
A_{0} Z_{i t}=A(L) Z_{i, t-1}+e_{i t}
$$

where $A_{0}$ is the matrix capturing the contemporaneous relationship between endogenous variables, $A(L)$ is a polynominial in the lag operator, and $e_{i t}$ is the vector of structural disturbances. The endogenous variables vector $Z$ is:

$$
Z_{i t}=\left[B_{i t}, G_{i t}, P_{i t}, T_{i t}, I_{i t}, C_{i t}\right]
$$

where $B$ indicates the stock of government gross financial liabilities, $G$ is government consumption, $P$ is the price level, $T$ net tax revenue, $I$ private investment, and $C$ private consumption. All variables are real,in logs, per capita and deflated by their own deflator ${ }^{5}$. The reduced form which is actually taken to estimation is obtained pre-multypling (1) by $A_{0}^{-1}$ so to have:

$$
Z_{i t}=B(L) Z_{i, t-1}+u_{i t}
$$

where $B(L)=A_{0}^{-1} A(L)$ and $u_{i t}=A_{0}^{-1} e_{i t}$ is the residual form vector.

Identification is achieved applying a lower triangular Cholesky decomposition with the ordering as in $(2)^{6}$ Individual country's heterogeneity is accounted for by introducing fixed effects. The system is estimated via GMM method (Love and Zicchino, 2006).

Figure 1 shows the impulse response functions related to a one per cent increase in government consumption. Focusing on the upper-right panel, we notice a positive and significant effect on private consumption.

\section{FIGURE 1 ABOUT HERE}

Table 1 reports point estimates in order to better asses the size of private consumption multiplier:

\section{Table 1: estimated consumption multipliers}

\footnotetext{
${ }^{5}$ Data sources are OECD Economic Outlook n.84, Main Economic Indicators (published by the European Commission) and the World Development Indicators (published by the World Bank).

${ }^{6}$ See the paper for a thorough discussion of the identification strategy.
} 


\begin{tabular}{cc}
\hline \hline period & $\frac{d C}{d G}$ \\
\hline \hline 0 & $0.26^{* * *}$ \\
\hline \hline 1 & $0.21^{* * *}$ \\
\hline \hline 2 & $0.11^{* * *}$ \\
\hline \hline 3 & $0.05^{* *}$ \\
\hline \hline 4 & 0.02 \\
\hline \hline 5 & 0.01 \\
\hline \hline 6 & -0.01 \\
\hline
\end{tabular}

Next section develops a theoretical framework able to account for the abovereported multipliers without assuming credit-constrained agents or consumption habits.

\section{The model}

Our baseline specification considers a cashless New Keynesian DSGE model with costly capital accumulation, price stickiness a-là-Rotemberg and a considerable degree of real distortions such as monopolistic competition in the intermediate good sector and distortionary tax rates on labor and capital income. Monetary policy follows a standard Taylor rule and fiscal policy finances a non-wasteful flow of public expenditure following debt-pegging tax rules. Next three subsections describe the behaviour of, respectively, the households sector, firms and policy authorities.

\subsection{Households}

Demand side is approximated by the presence of a representative infinitely-lived consumer whose preferences are defined over a composite consumption basket $\left(\tilde{C}_{t}\right)$ to be defined below, and labor effort $\left(N_{t}\right)$, according to the utility function:

$$
E_{0} \sum_{t=0}^{\infty} \beta^{t} U\left(\tilde{C}_{t}, N_{t}\right)
$$

where $E_{t}$ denotes the mathematical expectations operator conditional on the time- $t$ information set, $\beta \in(0.1)$ is the discount factor. The period utility function $U(\bullet)$ is assumed to be strictly increasing in its first argument, strictly decreasing in the second, and strictly concave, according to the following functional form

$$
U\left(\tilde{C}_{t}, N_{t}\right)=\frac{\tilde{C}_{t}}{1-\gamma}-\frac{a_{n}}{1+\gamma_{n}} N_{t}^{1+\gamma_{n}}
$$


where $\gamma>0$ is the intertemporal elasticity of consumption, $\gamma_{n}>0$ is the inverse of the Frisch elasticity of labor supply and $a_{n}>0$ a constant indicating the relative disutility of labor effort. $\tilde{C}_{t}$ denotes a consumption bundle defined as a Constant Elasticity of Substitution (CES) aggregator of public and private consumption as in Linneman and Schabert (2004) and Bouakez and Rebei $(2007)^{7}$ :

$$
\tilde{C}_{t}=\left[\theta C_{t}^{\frac{v-1}{v}}+(1-\theta)\left(z G_{t}\right)^{\frac{v-1}{v}}\right]^{\frac{v}{v-1}}
$$

with $G_{t}$ being total public expenditure and $0<z<1$ is the non-wasteful fraction which - alternatively - complements or substitutes private consumption. Parameter $v>0$ denotes the intertemporal elasticity of substitution between private and (useful) public consumption and is the relative weight of the two variables in the CES aggregator. When $v=0, C_{t}$ and $G_{t}$ are perfect complements, when $v \rightarrow \infty$ they are perfect substitutes.

In our framework, public expenditure complements or substitute private consumption to the extent it affects its marginal utility. By differentiating (5) with respect to $C_{t}$ we obtain the expression for the marginal utility of private consumption:

$$
\frac{\partial U}{\partial C_{t}}=\theta C_{t}^{-\frac{1}{\nu}}\left[\theta C_{t}^{\frac{v-1}{v}}+(1-\theta) G_{t}^{\frac{v-1}{v}}\right]^{\frac{-\gamma v+1}{v-1}}
$$

The cross-derivative with respect to $G_{t}$ amounts to:

$$
\frac{\partial U}{\partial C_{t} \partial G_{t}}=\theta(1-\theta) \frac{-\gamma v+1}{v} G_{t}^{-\frac{1}{v}}\left[\theta C_{t}^{\frac{v-1}{v}}+(1-\theta) G_{t}^{\frac{v-1}{v}}\right]^{\frac{-\gamma v-v+2}{v-1}}
$$

It is easily verifiable that:

$$
\operatorname{sign} \frac{\partial U}{\partial C_{t} \partial G_{t}}=\operatorname{sign} \frac{-\gamma v+1}{v}=\operatorname{sign}(-\gamma v-1)
$$

Therefore, $C_{t}$ and $G_{t}$ and are complements whenever $v<\frac{1}{\gamma}$, substitutes if $v>\frac{1}{\gamma}$. If, on the other hand, $v=\frac{1}{\gamma}$ government spending does not affect the marginal utility of consumption and the model collapses to the standard case of wasteful government consumption.

The household's flow budget constraint in real terms is given by:

$$
\frac{B_{t}}{P_{t}}+C_{t}+I_{t}+T_{t}^{0}=\left(1-\tau_{t}^{w}\right) w_{t} N_{t}+\left(1-\tau^{k}\right) R_{t} K_{t}+\frac{i_{t-1} B_{t-1}}{P_{t}}+\Psi_{t}
$$

where $B$ is the nominal stock of one-period riskless government bonds, $I_{t}$ denotes investment, $T_{t}^{0}$ lump-sum taxes, $w_{t}$ the real wage, $R_{t}$ the rental rate

\footnotetext{
${ }^{7}$ A very similar specification is also used in Forni et al (2010).
} 
at which households lend capital to firms, $i$ is the gross nominal interest rate, $\tau_{t}^{i}$ (with $i=w, k$ ) the distortionary tax rate on, respectively, labor and capital income, and $\Psi_{t}$ is the economic profits deriving from ownership of monopolistically competitive firms.

Capital stock $K_{t}$ depreciates at the constant rate $0<\delta<1$ and its accumulation is subject to convex adjustment costs, so that evolution of capital is given by:

$$
K_{t+1}=(1-\delta) K_{t}+I_{t}-\frac{\psi}{2}\left(\frac{I_{t}}{K_{t}}-\delta\right)^{2} K_{t}
$$

denoting that a marginal increase in the investment/capital ratio with respect to its steady-state level is penalized in terms of $\psi$ unit of capital which gets lost in the process. The representative household is also constrained by the usual transversality condition ruling out Ponzi schemes.

The household's problem consists in choosing the levels of consumption, labor effort, investment, capital stock and nominal bond holdings in order to maximize the intertemporal utility function (4) subject to (9), (10) and the transversality condition. Optimality conditions are:

$$
\begin{aligned}
\theta \tilde{C}_{t}^{-\gamma+\frac{1}{v}} C_{t}^{-\frac{1}{v}}= & \lambda_{t} \\
\lambda_{t}\left(1-\tau_{t}^{w}\right) w_{t}= & a_{n} N_{t}^{\gamma_{n}} \\
\lambda_{t}= & \mu_{t}\left[1-\psi\left(\frac{I_{t}}{K_{t}}-\delta\right)\right] \\
\mu_{t}= & \beta \lambda_{t+1}\left(1-\tau_{t+1}^{R}\right) R_{t+1}+ \\
& +\beta \mu_{t+1}\left[(1-\delta)+\frac{\psi}{2}\left(\left(\frac{I_{t+1}}{K_{t+1}}\right)^{2}-\delta^{2}\right)\right] \\
\lambda_{t}= & \beta E_{t} \lambda_{t+1} \frac{P_{t}}{P_{t+1}} i_{t}
\end{aligned}
$$

where $\lambda_{t}$ and $\mu_{t}$ denote the Lagrange multipliers associated with, respectively, constraints (13) and (14).

\subsection{Firms}

The supply-side of the model economy is represented by two sectors.

A perfectly competitive final good sector assembles the final output $Y_{t}$, which can be used for internal absorption (private consumption $C_{t}$, investment $I_{t}$ or government expenditure $G_{t}$ ), according to the CES production function:

$$
Y_{t}=\left[\int_{0}^{1} Y_{i t}^{\frac{\eta-1}{\eta}} d i\right]^{\frac{\eta}{\eta-1}}
$$


where $Y_{i t}$ (with $i \in(0,1)$ ) is the $i$-th variety of the intermediate goods produced by firm $i$, and $\eta>1$ is the constant elasticity of substitution between any two varieties. Cost minimization by final good firms lead to the following negative sloped demand schedule for intermediate products::

$$
Y_{i t}=\left(\frac{P_{i t}}{P_{t}}\right)^{-\eta} Y_{t}
$$

where $P_{i t}$ is the price of good $i$ set by the corresponding monopolistically competitive firm- $i, P_{t}$ is the general price index given by the Dixit-Stiglitz aggregator $P_{t}=\left[\int_{0}^{1} P_{i t}^{1-\eta} d i\right]^{\frac{1}{1-\eta}}$ and $Y_{t}$ denotes aggregate demand.

Intermediate goods firms produce according to the following Cobb-Douglas production function:

$$
Y_{i t}=A_{t} K_{i t}^{\alpha} N_{i t}^{1-\alpha}-\Phi
$$

where $K_{i t}$ and $N_{i t}$ are, respectively, capital and labor services employed by firm $-i, \Phi$ is a fixed cost of production whose role is to soak up steadystate profits, and $A_{t}$ is an aggregate productivity following an $\operatorname{AR}(1)$ stochastic process such as:

$$
\log \frac{A_{t}}{\bar{A}}=\rho_{A} \log \frac{A_{t-1}}{\bar{A}}+\varepsilon_{t}^{A}
$$

where $\bar{A}$ denotes steady-state technology, $0<\rho_{A}<1$ the autoregressive parameter, and $\varepsilon_{t}^{A} \sim\left(0, \sigma_{A}^{2}\right)$ a stochastic shock.

The intermediate good sector features a nominal rigidity through the presence of quadratic adjustment costs (Rotemberg 1982) in nominal price-setting, of the form:

$$
A C^{P}=\frac{\phi_{p}}{2}\left(\frac{P_{i t}}{P_{i t-1}}-\bar{\pi}\right)^{2} Y_{t}
$$

meaning that every deviation of good- $i$ gross inflation rate from steady-state general price index inflation costs $\phi_{p}$ units of output.

Each intermediate producers charge the optimal price $\tilde{P}_{i t}$, which is set so to maximize the expected present discounted value of nominal profits, subject to production (equation 18) and demand (equation 17) constraints. Formally:

$$
\max _{P_{i t}} \Pi_{i 0}=E_{0}\left[\sum_{t=0}^{\infty} \Lambda_{t} P_{t} \Pi_{i t}\right]
$$

where real profits $\Pi_{i t}$ are given by:

$$
\Pi_{i t}=\frac{P_{i t}}{P_{t}} Y_{i t}-R_{t} K_{i t}-w_{t} N_{i t}-A C^{P}
$$

subject to: 


$$
\begin{aligned}
Y_{i t} & =A_{t} K_{i t}^{\alpha} N_{i t}^{1-\alpha}-\Phi_{t} \\
Y_{i t} & =\left(\frac{P_{i t}}{P_{t}}\right)^{-\varepsilon} Y_{t} \\
A C^{P} & =\frac{\phi_{p}}{2}\left[\frac{P_{j t}}{P_{i, t-1}}-\bar{\pi}_{t}\right]^{2} Y_{t}
\end{aligned}
$$

and $\Lambda_{t}$ is the stochastic discount factor.

Maximization leads to the following factor prices:

$$
\begin{gathered}
R_{t}=\alpha\left(1-\frac{1}{\varepsilon_{i t}^{Y}}\right)\left(\frac{Y_{j t}+\Phi}{K_{i t}}\right) \\
w_{t}=(1-\alpha)\left(1-\frac{1}{\varepsilon_{i t}^{Y}}\right)\left(\frac{Y_{j t}+\Phi}{N_{i t}}\right)
\end{gathered}
$$

with $\varepsilon_{i t}^{Y}$, being the output demand elasticity:

$$
\frac{1}{\varepsilon_{i t}^{Y}}=\eta^{-1}\left[\begin{array}{c}
1-\phi_{p}\left(\frac{P_{i t}}{P_{i, t-1}}-\bar{\pi}\right) \frac{P_{t}}{P_{i, t-1}} \frac{Y_{t}}{Y_{i t}} \\
+\beta E_{t} \phi_{p} \frac{\Lambda_{t+1}}{\Lambda_{t}}\left(\frac{P_{i, t+1}}{P_{i, t}}-\bar{\pi}\right) \frac{P_{t+1}}{P_{i t}} \frac{P_{i, t+1}}{P_{i t}} \frac{Y_{t+1}}{Y_{i t}}
\end{array}\right]
$$

With perfect price flexibility $\left(\phi_{p}=0\right)$ or in steady-state $\left(\pi_{t}=\pi_{t+1}=\bar{\pi}\right)$ expression (25) simplifies to $\varepsilon_{i t}^{Y}=\eta$, so that the mark-up is a decreasing function of the elasticity of substitution across intermediate goods. In such situation, stochastic shocks do not change the mark-up, with the only differences being that technological or fixed-cost shocks affect real variables, whereas demand shocks do not. With price stickiness, mark-up becomes a transmission channel for the business cycle, through its own cyclicality whose direction relies on the source of the shock (Kim 1998): production function shocks leading to a reduction of marginal costs increase output and the mark-up, whereas demand side shocks (shifting upward the profit-maximizing equality between marginal and revenue and marginal costs) increase output but lead to a cut in the mark-up.

\subsection{The policy side}

Public sector consists of central bank and government. The central bank is in charge of monetary policy, implemented by setting nominal interest rate according to a standard Taylor rule such as:

$$
\ln \frac{i_{t}}{\bar{\imath}}=\phi_{\pi} \ln \left(\frac{\pi_{t}}{\bar{\pi}}\right)+\phi_{y} \ln \left(\frac{y_{t}}{\bar{y}}\right)
$$

where $\bar{\pi}$ and $\bar{y}$ indicate, respectively, the steady-state levels of inflation and output. 
The government is in charge of fiscal policy; flow budget constraint in nominal terms is given by:

$$
B_{t}=i_{t-1} B_{t-1}+P_{t}\left(z G_{t}+(1-z) G_{t}\right)-P_{t} T_{t}
$$

where $z G_{t}$ and $(1-z) G_{t}$ are, respectively, the useful and wasteful share of public expenditure.

The overall amount $G_{t}$ evolves according to a $\operatorname{AR}(1)$ stochastic process:

$$
\log \frac{G_{t}}{\bar{G}}=\rho_{g} \log \frac{G_{t-1}}{\bar{G}}+\varepsilon_{t}^{G}
$$

where $\bar{G}$ denotes steady-state technology, $0<\rho_{g}<1$ the autoregressive parameter, and $\varepsilon_{t}^{G} \sim\left(0, \sigma_{g}^{2}\right)$ a stochastic shock. In $(27) T_{t}$ denotes real total tax revenue, made of distortionary taxation and a residual lump-sum revenue $T^{0}$ so that:

$$
T_{t}=T^{0}+\tau_{t}^{w} w_{t} N_{t}+\tau_{t}^{R} R_{t} K_{t}
$$

By expressing nominal budget constraint (28) in real terms we obtain the dynamics of real government debt:

$$
b_{t}=\frac{i_{t-1}}{\pi_{t}} b_{t-1}+z G_{t}+(1-z) G_{t}-T_{t}
$$

where $b_{t}$ denotes the real stock of public debt and $\pi_{t}$ is the inflation rate at time $t$.

The government conducts fiscal policy by setting the two distortionary tax rates on both capital and labor income according to a simple feedback rule on deviations of last period real stock of public debt from its steady-state level:

$$
\begin{aligned}
\tau_{t}^{w} & =\bar{\tau}^{w}+\phi^{w}\left(b_{t-1}-\bar{b}\right) \\
\tau_{t}^{R} & =\bar{\tau}^{R}+\phi^{R}\left(b_{t-1}-\bar{b}\right)
\end{aligned}
$$

Note that (31) and (32) differ from similar specifications (such as SchmittGrohè and Uribe 2007) where the overall tax revenue is the fiscal policy instrument and reacts to debt deviations. Indeed, we believe that using the actual tax rate (on labor or capital income) as the variable directly under government's control constitutes a more accurate representation of real world fiscal policy decisions. Under this respect, we believe that this adds a more realistic structure to the fiscal side of the model, not previously considered in the literature.

\section{Equilibrium and calibration}

\subsection{Definition of equilibrium}

We assume the existence of a complete and competitive market for contingent claims, so that firms discount their future profits the same way households dis- 
count their future consumption flows $\left(\beta \frac{\lambda_{t+1}}{\lambda_{t}}=\frac{\Lambda_{t+1}}{\Lambda_{t}}\right)$.A symmetric competitive rational expectations equilibrium is defined as a sequence of prices:

$$
\left\{\mathbf{P}_{t}\right\}_{0}^{\infty}=\left\{P_{t}^{*}, R_{t}^{*}, i_{t}^{*}, w_{t}^{*}\right\}_{t=0}^{\infty}
$$

quantities

$$
\left\{\mathbf{Q}_{t}\right\}_{t=0}^{\infty}=\left\{Y_{t}^{*}, C_{t}^{*}, I_{t}^{*}, G_{t}^{*}, N_{t}^{*}, K_{t+1}^{*}, T_{t}^{*}, B_{t}^{*}, \tau_{t}^{*}\right\}_{t=0}^{\infty}
$$

and stochastic shocks

$$
\left\{\varepsilon_{t}\right\}_{t=0}^{\infty}=\left\{\varepsilon_{t}^{A}, \varepsilon_{t}^{g}\right\}_{t=0}^{\infty}
$$

bounded in a neighbourhood of the deterministic steady state, such that given initial stocks of capital and public debt the optimality conditions for households and firms are satisfied in each period $t$, goods, capital, labor and bond markets clear, transversality conditions hold, government budget constraints and policy rules are satisfied, aggregate resource constraints $\left(Y_{t}=C_{t}+I_{t}+G_{t}+A C_{t}^{P}\right)$ holds. The complete set of equilibrium conditions can be found in Appendix A.

\subsection{Calibration}

The model is calibrated on European Union economy from 1990 to 2008. Time unit is chosen to be one quarter, and deep parameters are picked up accordingly. Steady-state annual inflation rate is assumed to be 3.02 per cent, and the discount factor discount factor $\beta$ is set at 0.9902 . We assume that households devote one third of their total amount of time to labor effort $(N=0.33)$; steady-state government debt is set to be 60 per cent of real GDP. In setting the value for steady-state $\bar{G}$, we sum up government consumption and investment so to have a ratio of 32.08 per cent of GDP. In the benchmark calibration we assume that $z=1$ (all spending is either substitute or complement to private consumption). Private investment share of GDP is 11.29 and total tax revenue/GDP ratio is 31.66.

Structural parameters of the model are set according to Table 2.

Table 2: Structural Parameter calibration and description 


\begin{tabular}{lll} 
Parameter & Value & Description \\
\hline \hline$\gamma$ & 2 & risk adversion coefficient \\
$\theta$ & 0.8 & preference parameter \\
$\gamma_{n}$ & 0.55 & inverse of Frisch elasticity \\
$\beta$ & 0.9902 & discount factor \\
$\delta$ & 0.025 & depreciation rate \\
$\alpha$ & 0.33 & capital share \\
$\phi_{k}$ & 2.48 & capital adjustment cost \\
$\eta$ & 5 & price elasticity of demand \\
$\rho_{A}$ & 0.95 & serial correlation of productivity \\
$\rho_{G}$ & 0.90 & serial correlation of govt spending \\
$\sigma_{A}$ & 0.07 & standard deviation of $A$-shock \\
$\sigma_{G}$ & 0.01 & standard deviation of $G$-shock \\
\hline
\end{tabular}

Parameter $\theta$, denoting the relative weight of private and public consumption in the utility function, is set at the same value used by the only paper which - to the best of our knowledge - has employed and calibrated this utility function specifications before us (Bouakez and Rebei 2007). The price elasticity of demand $\eta$ is set equal to 5 so to be consistent with a steady-state net mark-up of 25 per cent. The value of the capital adjustment cost parameter $\left(\phi_{k}=2.48\right)$ is taken from Christiano et al (2005). Parameter $\phi_{p}$ denoting the degree of nominal price rigidity is set equal to 100, as in Ireland (1997).

Finally, first and second moments of the stochastic shocks are in line with current business cycle literature.

In developing our results we carry out counterfactual exercises along two dimension sets. The first one involves the nature of public expenditure (the Edgeworth complementarity/substitutability and the share of non-wastefulness), the second is concerned with policy (monetary and fiscal policy feedback parameters $\left(\phi^{w}, \phi^{R}, \phi_{y}\right)$.

As mentioned in section 2.1, (equation 9) the nature of the relation between government expenditure and public consumption is given by sign of the expression $v-\frac{1}{\gamma}$; having fixed the risk adversion coefficient at the standard value of 2, we determine the Edgeworth complementarity or substitutability of public expenditure by varying the elasticity of substitution $v$. At the reference value of 0.5 , the flow of government spending does not affect private consumption at all ("benchmark"); at $v=0.8(>0.5)$ there will be substitutability, and at $v=0.2$ $(<0.5)$ there will be complementarity.

Monetary policy parameter $\phi_{\pi}$ and $\phi_{y}$ are set at the conventional values of, respectively, 1.5 and 0.5 . Steady-state tax rates on capital and labor income are set such that $\bar{\tau}^{w}=0.40$ and $\bar{\tau}^{R}=0.20$ as average in our sample.

The model is solved through first-order approximation around the deterministic steady-state by using Sims (2001) algorithm. 


\section{Results}

In this section we present our results, which are mainly concerned with the response of the relevant endogenous variables to a one-standard deviation governmnent spending shock. Particular attention is devoted to the quantitative side of the implied output and consumption multipliers. Subsection 4.1. develops our basic intuition, while the following two illustrate our results under - respectively- wasteful and non-wasteful government spending. Subsection 4.4 strenghtens the intuition on the underlying mechanism by comparing results obtained under different versions of the theoretical model.

\subsection{The intuition}

By elaborating on Hall (2009a), we provide an intuitive representation of the driving forces at work in our setting, in order to facilitate the interpretation of results. If we combine first order conditions on consumption (equation 12) and leisure (equation 13) we obtain a static general equilibrium condition for the optimal mix of consumption and hours worked:

$$
U^{\prime}\left(N_{t}\right)=\left(1-\tau_{t}^{w}\right) w_{t} U^{\prime}\left(C_{t}\right)
$$

with the usual concavity and convexity assumptions $U^{\prime}(N)>0, U^{\prime \prime}(N)>0$ and $U^{\prime}(C)>0, U^{\prime \prime}(C)<0$.

Equation (33) states the equality between the marginal cost of supplying a time unit of work (left-hand-side) and the net marginal benefits in utility terms (right-hand-side).

An impulse in $G$ raises left-hand-side via the income-effect and the convexity assumption with respect to the labor effort argument. In the right-hand side, although gross real wage $w_{t}$ increases because of price stickiness, the fiscal policy rule trying to stabilize debt increases $\tau_{t}^{w}$ and thus decreases the net real wage. Since condition (33) must hold during the transitional dynamics, then $U_{\prime}\left(C_{t}\right)$ must increase, meaning that the consumption level must decrease due to concavity assumption of the utility function with respect to the consumption argument.

The analysis of optimal condition (33) allows us to understand the transmission mechanism of fiscal policy along both dimensions of revenue (the effects of the distortionary wage taxation) and expenditure (whenever public expenditure is "non-wasteful" and therefore affects $U^{\prime}\left(C_{t}\right)$ positively or negatively).

On the revenue side, given the left-hand-side increase, the higher the response of the labor income tax rate $\left(\tau_{t}^{w}\right)$, the higher the increase in marginal utility of consumption that is needed in order to remain on the optimal path, and the higher the required drop in consumption.

On the expenditure side, a shock in $G$ can either increase or decrease $U^{\prime}(C)$, depending on whether the elasticity of substitution between public and private consumption $\nu$ is - respectively - lower or higher than the intertemporal elasticity of substitution given by the inverse of risk adversion parameter $\left(\frac{1}{\gamma}\right)$. If public 


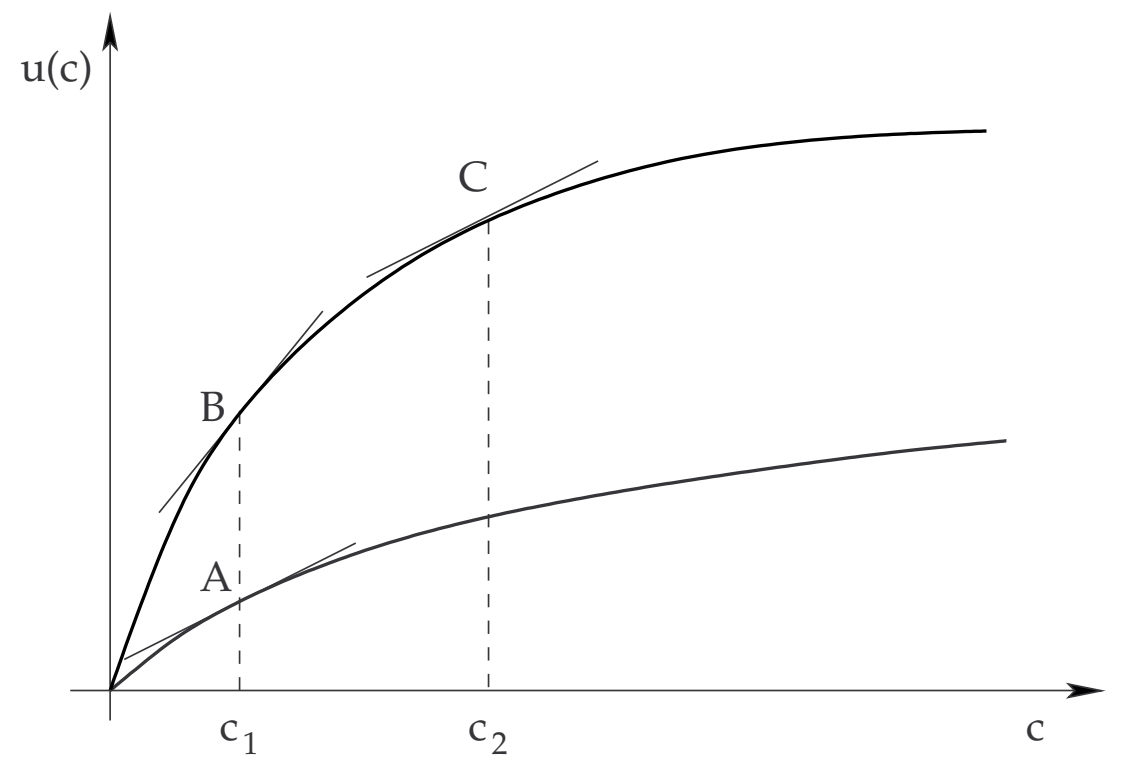

Figure 1:

expenditure complements private consumption, this produces an impact raise in $U^{\prime}(C)$ according to equation (9); by keeping constant the movement of $\tau_{t}^{w}$ (given by the fiscal rule), this results in a higher labor supply's outward shift and thus an higher output multiplier. This is why under Edgeworth complementarity we expect higher consumption and output multipliers: the former by construction, the latter through general equilibrium effects given by (33).

If, on the other hand, public expenditure Edgeworth substitutes private consumption, we have the opposite effects: $U^{\prime}\left(C_{t}\right)$ decreases and therefore labor supply shift can be very modest, especially if the response of $\tau_{t}^{w}$ is particularly strong.

The following figure depicts the "core" of our intuition: starting from point A, a shock to Edegworth complement public expenditure $G$ shifts both the utility frontier and its slope to point B. It is obvious that the slope's change represents an increase in marginal utility of private consumption according to (9). Therefore, to restore the ex-ante marginal utility, consumption level must increase up to point $\mathrm{C}$, where the slope is same as in point $\mathrm{A}$. It is worth to note that point $\mathrm{C}$ represents the impact right after the shock to $G$. Afterwards - due to the autoregressive structure imposed on the stochastic process driving $\mathrm{G}$ - the level of public spending gets period by period lower: this implies furher downward shifts of the utility function back to the original position. This, in turn, inserts a transitional dynamics where both consumption and its marginal utility are above the pre-shock starting level. 
A general equilibrium condition analogous to (33) can be derived for the capital accumulation process. In fact, combining first order conditions on $K_{t+1}$ (equation 15) and $I_{t}$ (equation 14) we obtain a dynamic condition stating the equality between the marginal cost of saving (the foregone marginal utility of consumption) and its marginal benefits (in terms of augmented capital stock and factor income) net of adjustment costs:

$\frac{U^{\prime}\left(C_{t}\right)}{1-\psi\left(\frac{I_{t}}{K_{t}}-\delta\right)}=\beta U^{\prime}\left(C_{t+1}\right)\left(1-\tau_{t+1}^{R}\right) R_{t+1}+\beta \mu_{t+1}\left[(1-\delta)+\frac{\psi}{2}\left(\left(\frac{I_{t}}{K_{t}}\right)^{2}-\delta^{2}\right)\right]$

The analysis on the revenue side of fiscal policy is easy: an increase in the tax rate on capital discourages capital accumulation by diminishing the net marginal benefits of savings (note that, since the equation is dynamic and the relevant tax rate is indexed $t+1$, a shock in government debt at period $t$ produces only a delayed effect). A shock in Edgeworth complement government expenditure raises the marginal cost of savings and therefore discourages capital accumulation, as it is perfectly intuitive as current aggregate consumption increases ${ }^{8}$. However, as far as overall effect on output multiplier is concerned, we should also remember the different factor shares of capital and labor in the production function (with the former being calibrated at the conventional value of 0.3 against 0.7 for the latter). Therefore, the negative effect on capital accumulation contributes to output multiplier's magnitude less than the positive effect on labor effort.

\subsection{Wasteful government expenditure}

Figure 2 here below shows the impulse response functions after a one standard deviation shock in wasteful government expenditure $\left(v=0.5=\frac{1}{\gamma}\right)$.

\section{FIGURE 2 ABOUT HERE}

Here our model behaves as a standard DSGE with nominal rigidities: an unexpected increase in government spending raises future tax burden (although our fiscal rules ensure a partial increase in distortionary taxation the period after the shock) and therefore increase labor supply. Nominal rigidities shifts also the labor demand curve, and both movements result in a real wage increase. The positive output multiplier $\left(\frac{d Y}{d G}>0\right)$ results from the increase in labor effort, while the negative consumption multiplier $\left(\frac{d C}{d G}<0\right)$ arises from the negative wealth effect. Absent any liquidity constraint (and any complementarity between labor supply and consumption), the increase in real wage is not

\footnotetext{
${ }^{8}$ However, the marginal utility of consumption's upward shifts does not die out after one period; therefore, also $U^{\prime}\left(C_{t+1}\right)$ on the RHS of (30) is higher, so the overall effect is less relevant.
} 
enough to generate a positive consumption response. Multipliers' numerical values after two, four and eight quarters are in line with previous literature but, again, distant from empirical evidence :

Table 3: Fiscal Policy Multipliers with wasteful government expenditure

\begin{tabular}{llllll}
$\frac{d Y}{d G}(Q 2)$ & $\frac{d Y}{d G}(Q 4)$ & $\frac{d Y}{d G}(Q 8)$ & $\frac{d C}{d G}(Q 2)$ & $\frac{d C}{d G}(Q 4)$ & $\frac{d C}{d G}(Q 8)$ \\
\hline \hline 0.05 & 0.10 & 0.10 & -0.18 & -0.55 & -1.28
\end{tabular}

Investigating the sensitivity of multipliers'magnitude on fiscal and monetary policy parameters, we can find out that the higher the responses of respectively - tax rates to debt and interest rate to output - the lower multipliers are.

Results are shown in Tables 4 and 5 here below:

Table 4: Sensitivity of Fiscal Policy Multipliers to monetary policy parameter

\begin{tabular}{l|llllll}
$\begin{array}{l}\text { monetary rule } \\
\text { parameters }\end{array}$ & $\frac{d Y}{d G}(Q 2)$ & $\frac{d Y}{d G}(Q 4)$ & $\frac{d Y}{d G}(Q 8)$ & $\frac{d C}{d G}(Q 2)$ & $\frac{d C}{d G}(Q 4)$ & $\frac{d C}{d G}(Q 8)$ \\
\hline \hline$\tau^{w}, \tau^{R}=0.1$ & 0.05 & 0.10 & 0.10 & -0.18 & -0.55 & -1.28 \\
$\phi_{y}=0$ & 0.16 & 0.38 & 0.56 & -0.10 & $-0.42 ;$ & -1.01 \\
\hline
\end{tabular}

Given the fiscal rule outlined in equations (27)-(28), a monetary policy rule with no response to output, by setting $\phi_{y}=0$, output reduces the intertemporal substitution effect which, via the increase in the interest rate following the expansionary effect of the government expenditure stimulus, dampens the response of output and consumption.

Table 5: Sensitivity of Fiscal Policy Multipliers to fiscal policy parameter

\begin{tabular}{l|llllll}
$\begin{array}{l}\text { fiscal rule } \\
\text { parameters }\end{array}$ & $\frac{d Y}{d G}(Q 2)$ & $\frac{d Y}{d G}(Q 4)$ & $\frac{d Y}{d G}(Q 8)$ & $\frac{d C}{d G}(Q 2)$ & $\frac{d C}{d G}(Q 4)$ & $\frac{d C}{d G}(Q 8)$ \\
\hline \hline$\tau^{w}, \tau^{R}=0.1$ & 0.05 & 0.10 & 0.10 & -0.18 & -0.55 & -1.28 \\
$\tau^{w}, \tau^{R}=0.5$ & 0.01 & 0 & -0.05 & -0.20 & -0.62 & -1.39 \\
$\tau^{w}, \tau^{R}=0.9$ & 0 & -0.01 & -0.07 & -0.21 & -0.68 & -1.47 \\
\hline
\end{tabular}

For a given monetary policy stance (equation (23)), increasing the tax rates response to debt accumulation reduces multipliers'magnitude because of their distortionary effects on labor and capital accumulation, already illustrated in the previous subsection.

The reliance of multipliers' sizes on the exact specification of monetary and fiscal policy rules is a first element worth attention. Recently, Christiano et al 
(2009) emphasize that the output multiplier can be substantially large (as high as 3.9) when the zero lower bound on the nominal interest rate binds, so that monetary policy reaction to the government expenditure shock is zero. In the next subsection we show that, in presence of non-wasteful government expenditure, monetary policy does not need to be confined in the lower bound for the multipliers to be empirically plausible: all we need is a muted output response in the Taylor rule. By the same token, the magnitude of fiscal policy feedback parameters plays a role (although quantitatively less relevant) in determining multipliers'sizes.

\subsection{Non-wasteful government expenditure}

First we examine the complementarity case, then we move to the substitutability scenario.

We set the elasticity of substitution between public spending and private consumption (parameter $v$ ) equal to 0.2 , so that according to equation (5) a government expenditure shock raises the marginal utility of private consumption (since $v<\frac{1}{\gamma}$ ). Figure 3 reports the corresponding effects on macroeconomic variables:

\section{FIGURE 3 ABOUT HERE}

Consistently with the intuition developed in subsection 4.1., we observe an increase in the level of private consumption, caused by the upward shift of the utility function; the resulting increase in the marginal utility - by equation (29) - causes a larger increase in labor supply, which has two effects: on one hand, increases the output multiplier (in spite of a larger decrease in capital accumulation), on the other it offsets the price-rigidity-induced labor demand shifts thereby causing a reduction in the real wage, marginal costs and inflation. Under active monetary policy (obtained by setting $\phi_{\pi}>1$ in (23)), this results in a more than proportional decrease in the nominal interest rate and therefore in a further expansionary effect on both output and consumption.

Output and consumption multipliers are:

Table 6: Fiscal policy multipliers with $v=0.2$

\begin{tabular}{llllll}
$\frac{d Y}{d G}(Q 2)$ & $\frac{d Y}{d G}(Q 4)$ & $\frac{d Y}{d G}(Q 8)$ & $\frac{d C}{d G}(Q 2)$ & $\frac{d C}{d G}(Q 4)$ & $\frac{d C}{d G}(Q 8)$ \\
\hline \hline 0.18 & 0.49 & 0.91 & 0.32 & 0.83 & 1.42 \\
\hline
\end{tabular}

The magnitude of consumption multipliers is considerable; however, it can be brought down by acting on two dimensions: (i) first, the share of non-wasteful government expenditure, (ii) second the fiscal rule parameter on debt. Table 6 shows the value of the consumption multiplier when only half of government expenditure is assumed to Edgeworth complement private consumption $(z=$ $0.5)$ and tax rates response to last-period debt is assumed to be more aggressive $\left(\phi^{w}=\phi^{R}=0.5\right)$ : 
Table 7: Private consumption multipliers with $z=0.5$ and $\phi^{w}=\phi^{R}=0.5$

\begin{tabular}{lll}
\hline \hline$\frac{d C}{d G}(Q 2)$ & $\frac{d C}{d G}(Q 4)$ & $\frac{d C}{d G}(Q 8)$ \\
\hline \hline 0.23 & 0.45 & 0.68 \\
\hline
\end{tabular}

These results - derived with no need of assuming credit-constrained agents and/or consumption habits - are very similar to the empirical estimates on the Euro-area by Marattin and Salotti (2009) and reported by Table 1 in Section 2: a consumption multiplier equal to 0.26 on impact, 0.47 after one year and 0.57 after two years. This is indeed the central results of our paper: empirical results indicating a positive effect of government spending shock on private consumption can be almost exactly replicated in a DSGE model with no need of assuming deviations from permanent income hypothesis or real rigidities in consumption patterns such as habit formation. All you need is a combination of partially useful government consumption and distortionary taxation targeting the stock of real debt.

As mentioned above, shutting off monetary policy's response to output largely increases multipliers' sizes. Table 7 shows our results with $\phi_{y}=0$ and $z=0.5$ tax rates at their steady-state level:

Table 8: Fiscal policy multipliers with muted monetary policy and complementarity

\begin{tabular}{llllll}
\hline \hline$\frac{d Y}{d G}(Q 2)$ & $\frac{d Y}{d G}(Q 4)$ & $\frac{d Y}{d G}(Q 8)$ & $\frac{d C}{d G}(Q 2)$ & $\frac{d C}{d G}(Q 4)$ & $\frac{d C}{d G}(Q 8)$ \\
\hline 0.42 & 1.12 & 2.08 & 0.46 & 1.22 & 2.24 \\
\hline
\end{tabular}

Therefore, in presence of Edgeworth complementarity- even partial- monetary policy can help achieving positive and significant multipliers with no need of the nominal interest rate's zero lower bound constraint being binding. Since public spending shock is actually deflationary (due to the large response of labor supply after the increase in the marginal utility of consumption), an active and exclusive monetary policy response to inflation reinforces the expansionary effect.

On the other hand, Edgeworth substitutability can probably explain cases where public expenditure stimulus has not succedeed in fulfilling its desiderd expansionary effect. In fact, as we set $v=0.8\left(>\frac{1}{\gamma}\right)$, these are the corresponding impulse response functions:

\section{FIGURE 3 ABOUT HERE}

Consistently with our intuition developed in subsection 4.1., now increase in labor supply is much smaller, and this consistently reduces the magnitude of the output multiplier. While it seems hard to justify the total substitutability between public expenditure and private consumption, a value of $z=0.5$ can reconcile our predictions with less drammatic - although still negative consumption multipliers (see Table 9). 
Table 9:Private consumption multipliers with $v=0.8$

\begin{tabular}{cccc}
\hline \hline & $\frac{d C}{d G}(Q 2)$ & $\frac{d C}{d G}(Q 4)$ & $\frac{d C}{d G}(Q 8)$ \\
\hline \hline$z=1$ & -0.26 & -0.76 & -1.66 \\
\hline \hline$z=0.5$ & -0.20 & -0.60 & -1.39 \\
\hline
\end{tabular}

\subsection{Models'comparisons}

In this subsection we check the consistency of our intuition by comparing our results with those obtained under two alternative flexible price versions of the model: one with the same fiscal behaviour (debt-pegging tax rules), and the other where the two distortionary tax rates are the only fiscal policy tools to balance the budget. We compare the magnitude of our implied multipliers under all scenarios: wasteful, complementary and substitute government expenditure. Results are showed in Table 10.

Table 10: Fiscal policy multipliers under different versions of the model

\begin{tabular}{|c|c|c|c|c|c|c|}
\hline & $\frac{d Y}{d G}(Q 2)$ & $\frac{d Y}{d G}(Q 4)$ & $\frac{d Y}{d G}(Q 8)$ & $\frac{d C}{d G}(Q 2)$ & $\frac{d C}{d G}(Q 4)$ & $\frac{d C}{d G}(Q 8)$ \\
\hline $\begin{array}{l}\text { Flexible prices with } \\
\text { balanced budget } \\
v=0.5 \\
v=0.2 \\
v=0.8\end{array}$ & $\begin{array}{l}-0.03 \\
0.29 \\
-0.08\end{array}$ & $\begin{array}{l}-0.10 \\
0.79 \\
-0.25\end{array}$ & $\begin{array}{l}-0.23 \\
1.55 \\
-0.52\end{array}$ & $\begin{array}{l}-0.22 \\
0.34 \\
-0.30\end{array}$ & $\begin{array}{l}-0.65 \\
0.89 \\
-0.89\end{array}$ & $\begin{array}{l}-1.44 \\
1.62 \\
-1.93\end{array}$ \\
\hline $\begin{array}{l}\text { Flexible prices } \\
\text { with public debt } \\
v=0.5 \\
v=0.2 \\
v=0.8\end{array}$ & $\begin{array}{l}0.22 \\
0.49 \\
0.17\end{array}$ & $\begin{array}{l}0.55 \\
1.31 \\
0.42\end{array}$ & $\begin{array}{l}0.89 \\
2.43 \\
0.61\end{array}$ & $\begin{array}{l}-0.14 \\
0.38 \\
-0.24\end{array}$ & $\begin{array}{l}-0.42 \\
1.01 \\
-0.68\end{array}$ & $\begin{array}{l}-0.94 \\
1.88 \\
-1.45\end{array}$ \\
\hline $\begin{array}{l}\text { Sticky prices } \\
v=0.5 \\
v=0.2 \\
v=0.8\end{array}$ & $\begin{array}{l}0.05 \\
0.18 \\
0.02\end{array}$ & $\begin{array}{l}0.10 \\
0.49 \\
0.03\end{array}$ & $\begin{array}{l}0.10 \\
0.91 \\
-0.01\end{array}$ & $\begin{array}{l}-0.18 \\
0.32 \\
-0.26\end{array}$ & $\begin{array}{l}-0.55 \\
0.83 \\
-0.76\end{array}$ & $\begin{array}{l}-1.28 \\
1.42 \\
-1.66\end{array}$ \\
\hline
\end{tabular}

Let us first analyse the flexible price framework. Multipliers are lower under balanced budget rule: in fact, neither public debt nor the lump-sum option are available to government. As a result, all the burden of the increase in (wasteful or not) public expenditure must be beared by distortionary tax rates, with the general equilibrium effect highlighted in subsection 4.1. Instead, allowing public debt and lump-sum taxation as means of financing public imbalances the extent of the distortions gets lower and therefore we obtain higher multipliers. 
With nominal rigidites - as already observed in section 4.2 - multipliers'sizes are affected by the intertemporal substitution operating through the Euler equation (i.e. the intertemporal allocation of consumption governed by interest rate movements, in turn affected by the inflationary public spending increase and by the positive output movement). This is the reason why under sticky prices both output and consumption multipliers are lower. As already noted, however, if monetary policy's response to output is zero, this effect is reduced and multipliers can be higher (still lower than flexible price case, though).

\section{Conclusions}

As exit strategies from the massive fiscal stimulus begin to be implemented in most countries - and important government spending cuts are yet to come - it has becoming increasingly harder to delay the question on which kind of government expenditure we ought to cut (increase) in order to minimize (maximize) the negative (positive) effects on the overall macroeconomic environment. The literature on business cycle fluctuations has traditionally regarded government expenditure as wasteful, meaning that its role is confined to be an exogenous stream of purchases by public authorities which, however, yields no utility whatsoever to any agent in the model economy. It is not uncommon to find expressions such as "the government buys an exogenous amount of output and throws it away".

In this paper, we aimed at exploring the general equilibrium consequences of allowing a full or partial flow non-wasteful public spending, so that it can per se increase or decrease marginal utility of private consumption.

Our main conclusion is that the ability of a fully-fledged DGSE model to deliver positive and empirically plausible consumption multipliers does not necessarily rely on specific devices such as deviations from permanent income hypothesis or complementarities between work effort and consumption which are very hard to be empirically tested. The insertion of (even partially) useful government expenditure - through the modification of the optimality conditions for factor supply in the households' problem - allows us to achieve positive consumption multipliers. On top of that, policy rules play a crucial role: we showed that a zero response of monetary policy to output - or, alternatively, a less distortionary fiscal policy mix - combined with a partial degree of Edgeworth complementarity manages to deliver consumption multipliers of the same magnitude of those found for the Euro-Area on the same time span employed for the calibration of our theoretical model. These results are achieved under price stickiness and with no need of assuming real rigidities such as credit-constrained agents or consumption habits.

Naturally, if on one hand this conclusion opens up a new device to reconcile theoretical predictions with empirical findings, on the other presents a number of new questions to be necessarily addressed if the approach has to be employed for policy analysis. How do we empirically identify and quantify the share of 
public expenditure which complements private consumption? How can we $a$ priori distinguish between wasteful and non-wasteful contributions? Moreover, how do we deal with the situation - not accounted for in this framework - where a government expenditure shock is the combination of Edgeworth complement and Edgeworth substitute components? Finally, an even more interesting issue would be an investigation of welfare properties of alternative fiscal rules under government expenditure complementarity or substitutability.

Nevertheless, the ultimate aim of this contribution was to suggest that even in a very stylized theoretical frameworks we can no longer avoid to consider the quality and not only the quantity of public expenditure whenever we wonder about its general equilibrium effects. 


\section{References}

[1] Barro,R., King, R. (1984), "Time Separable Preferences and Intertemporal Substitution Models of the Business Cycle", Quarterly Journal of Economics, 99,817-40.

[2] Baxter,M., King, R. (1993), "Fiscal Policy in General Equilibrium", American Economic Review, 83, 315-334.

[3] Bilbie,F. (2009), "Non-Separable Preferences and Frisch Labor Supply: One Solution to a Fiscal Policy Puzzle", Journal of Money, Credit and Banking

[4] Blanchard, O., Perotti, R. (2002), "An Empirical Characterization of the Dynamic Effects of Changes in Government Spending and Taxes on Output", Quarterly Journal of Economics 117 (4), 1329-68.

[5] Bouakez,H., Rebei,N. (2007)," Why Does Private Consumption Rise After a Government Spending Shock?", Canadian Journal of Economics, Vol.40, No.3.

[6] Coenen,G., Straub,R.(2005), "Does Government Spending Crowd in Private Consumption? Theory and Empirical Evidence for the Euro Area", International Finance, 8(3), 435-470.

[7] Christiano, L., Eichenbaum,M., Evans, C. (2005), "Nominal Rigidities and the Dynamic Effects of a Shock to Monetary Policy", Journal of Political Economy 113, 1-45.

[8] Christiano, L., Eichenbaum,M., Rebelo, S. (2009), "When is the Government Spending Multiplier Large?", NBER Working paper Series 15394 October 2009.

[9] Fatas,A.,Mihov,I.(2001)," The Effects of Fiscal Policy on Consumption and Employment: Theory and Evidence", mimeo, INSEAD

[10] Fiorito,R., Kollintzas,T.,(2004), "Public Goods, Merit Goods and the Relation between Private and Government Consumption", European Economic Review 48,6 : 1367-1398.

[11] Forni,L.,Gerali,A.,Pisani,M.,(2010)," The Macroeconomics of Fiscal Consolidation in a Monetary Union: the Case of Italy", Bank of Italy Discussion Papers N.747 - March 2010

[12] Galì,J.,Perotti,R.(2003), Fiscal Policy and Monetary Integration in Europe, Blackwell

[13] Galì,J.,Lopez-Salido,J.D.,Vallès,J., (2007), " Understanding the Effects of Goverment Expenditure on Consumption", Journal of the European Economic Association 5(1), 227-270. 
[14] Greenwood,J.,Hercowitz, Z, Huffman, W. (1988), "Investment, Capacity Utilization and the Real Business Cycle" , American Economic Review $78(3), 402-417$.

[15] Hall, R., (2009a), "By How Much Does GDP Rise if the Government Buys More Output?" , NBER Working paper 15496 November 2009

[16] Hall, R. (2009b), "Reconcilling Cyclical Movements in the Marginal Value of Time and the Marginal Product of Labor", Journal of Political Economy, 117 (2), pp.281-323.

[17] Hall, R., Milgrom, P. (2008), "The Limited Influence of Unemployment on the Wage Bargain", American Economic Review, 98(4), pp.1653-1674.

[18] Leeper, E., Walker, T., Yang,S., "Government Investment and Fiscal Stimulus in the Short and Long Runs" NBER Working paper 15153.

[19] Linneman, L. (2006), "The Effects of Government Spending on Private Consumption: a Puzzle?", Journal of Money, Credit and Banking, Vol.37, No.7.

[20] Linnemann,L., Schabert,A., (2004), "Can Fiscal Spending Stimulate Private Consumption?", Economic Letters 82, 173-179.

[21] Lopez-Salido,J.,Rabanal,D., (2006), "Government Spending and Consumption-Hours Preferences", Working paper 02/2006 la Caixa, Barcelona.

[22] Love, V., Zicchino, L., 2006. Financial Development and Dynamic Investment Behavior: Evidence from Panel VAR. Quarterly Review of Economics and Finance 46(2), 190-210.

[23] Marattin,L.,Salotti,S.(2010), "On the Usefulness of Government Spending in the Euro-Area", University of Bologna Working Paper Series No.686.

[24] Monacelli, T., Perotti, R., 2008. Openness and the Sectoral Effects of Fiscal Policy. Journal of the European Economic Association 6(2-3), 395-403.

[25] Mountford,A.,Uhlig, H., (2008), "What are the Effects of Fiscal Policy Shocks?", NBER Working Paper No.14551.

[26] Kim,J. (1998), "Monetary Policy in a Stochastic Equilibrium Model with Real and Nominal Rigidities", Finance and Economic Discussion Series 1998-02, Board of Governors of the Federal Reserve System (US).

[27] Perotti,R.,Monacelli, T., (2008), "Fiscal Policy,Wealth Effects and MarkUps", NBER Working Paper No.14584.

[28] Perotti,R.(2007), "In Search of the Transmission Mechanism for Fiscal Policy", Working paper IGIER - Università Bocconi (Milan, Italy). 
[29] Ramey,V.,Shapiro, M., (1997), "Costly Capital Reallocation and the Effects of Government Spending", Carnegie-Rochester Conference on Public Policy 48, June, 145-194.

[30] Ramey,V. (2008), "Identifying Government Spending Shocks: It's All in the Timing", University of California, San Diego, June.

[31] Ravn,M,.Schmitt-Grohe,S., Uribe,M., (2007), "Explaining the Effects of Government Spending Shocks on Consumption and the Real Exchange Rate", NBER Working paper No.13328.

[32] Romer,C., Bernstein,J.(2009), "The Job Impact of the American Recovery and Reinvestment Plan" Obama Transition Team, Washington D.C., January 9th.

[33] Romer,C., Romer, D., (2007), "The Macroeconomic Effects of Tax Changes: Estimates Based on a New Measure of Fiscal Shocks", Working paper, University of California, Berkeley.

[34] Rotemberg, J.,(1982), "Sticky Prices in the United States", Journal of Political Economy, 90,1187-1211.

[35] Schmitt-Grohè, S., Uribe,M. (2007), "Optimal Simple and Implementable Monetary and Fiscal Rules", Journal of Monetary Economics 52, 6, 17021725.

[36] Shimer, R. (2005), "The Cyclical Behaviour of Equilibrium Unemployment and Vacancies" , American Economic Review, 95(1), 24-49.

[37] Sims,C., (2001), "Solving Linear Rational Expectations Models", Journal of Computational Economics, 20(1-2), 1-20. 


\section{Appendix A}

The complete set of equilibrium equations:

$$
\begin{aligned}
& \theta \tilde{C}_{t}^{-\gamma+\frac{1}{v}} C_{t}^{-\frac{1}{v}}=\lambda_{t} \\
& \tilde{C}_{t}=\left[\theta C_{t}^{\frac{v-1}{v}}+(1-\theta)\left(z G_{t}\right)^{\frac{v-1}{v}}\right]^{\frac{v}{v-1}} \\
& \lambda_{t}\left(1-\tau_{t}^{w}\right) w_{t}=a_{n} N_{t}^{\gamma_{n}} \\
& \lambda_{t}=\mu_{t}\left[1-\psi\left(\frac{I_{t}}{K_{t}}-\delta\right)\right] \\
& \mu_{t}=\beta\left[\lambda_{t+1}\left(1-\tau_{t+1}^{R}\right) R_{t+1}+\mu_{t+1}\left[(1-\delta)+\frac{\psi}{2}\left(\left(\frac{I_{t+1}}{K_{t+1}}\right)^{2}-\delta^{2}\right)\right]\right] \\
& \lambda_{t}=\beta E_{t} \lambda_{t+1} \frac{P_{t}}{P_{t+1}} i_{t} \\
& K_{t+1}=(1-\delta) K_{t}+I_{t}-\frac{\psi}{2}\left(\frac{I_{t}}{K_{t}}-\delta\right)^{2} K_{t} \\
& Y_{i t}=A_{t} K_{i t}^{\alpha} N_{i t}^{1-\alpha}-\Phi \\
& R_{t}=\alpha\left(1-\frac{1}{\varepsilon_{i t}^{Y}}\right)\left(\frac{Y_{j t}+\Phi}{K_{i t}}\right) \\
& w_{t}=(1-\alpha)\left(1-\frac{1}{\varepsilon_{i t}^{Y}}\right)\left(\frac{Y_{j t}+\Phi}{N_{i t}}\right) \\
& \ln \frac{i_{t}}{\bar{\imath}}=\phi_{\pi} \ln \left(\frac{\pi_{t}}{\bar{\pi}}\right)+\phi_{y} \ln \left(\frac{y_{t}}{\bar{y}}\right) \\
& \log \frac{A_{t}}{\bar{A}}=\rho_{A} \log \frac{A_{t-1}}{\bar{A}}+\varepsilon_{t}^{A} \\
& \log \frac{G_{t}}{\bar{G}}=\rho_{G} \log \frac{G_{t-1}}{\bar{G}}+\varepsilon_{t}^{G} \\
& b_{t}=\frac{i_{t-1}}{\pi_{t}} b_{t-1}+z G_{t}+(1-z) G_{t}-T_{t} \\
& T_{t}=T^{0}+\tau_{t}^{w} w_{t} N_{t}+\tau_{t}^{R} R_{t} K_{t} \\
& \tau_{t}^{w}=\bar{\tau}^{w}+\phi^{w}\left(b_{t-1}-\bar{b}\right) \\
& \tau_{t}^{R}=\bar{\tau}^{R}+\phi^{R}\left(b_{t-1}-\bar{b}\right) \\
& Y_{t}=C_{t}+I_{t}+G_{t}+A C_{t}^{P} \\
& \varepsilon_{i t}^{Y^{-1}}=\eta^{-1}\left[\begin{array}{c}
1-\phi_{p}\left(\frac{P_{i t}}{P_{i, t-1}}-\bar{\pi}\right) \frac{P_{t}}{P_{i, t-1}} \frac{Y_{t}}{Y_{i t}} \\
+\beta E_{t} \phi_{p} \frac{\Lambda_{t+1}}{\Lambda_{t}}\left(\frac{P_{i, t+1}}{P_{i, t}}-\bar{\pi}\right) \frac{P_{t+1}}{P_{i t}} \frac{P_{i, t+1}}{P_{i t}} \frac{Y_{t+1}}{Y_{i t}}
\end{array}\right]
\end{aligned}
$$


Response of delt

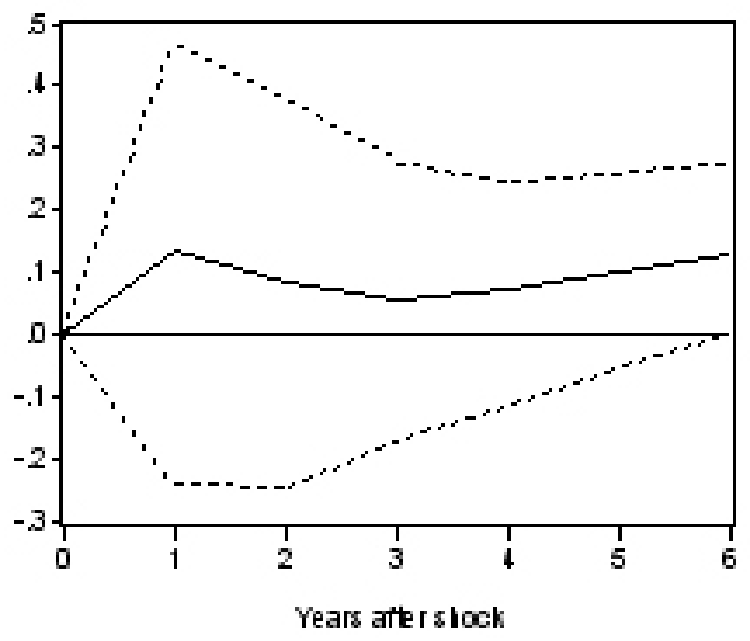

Response of pubic spending

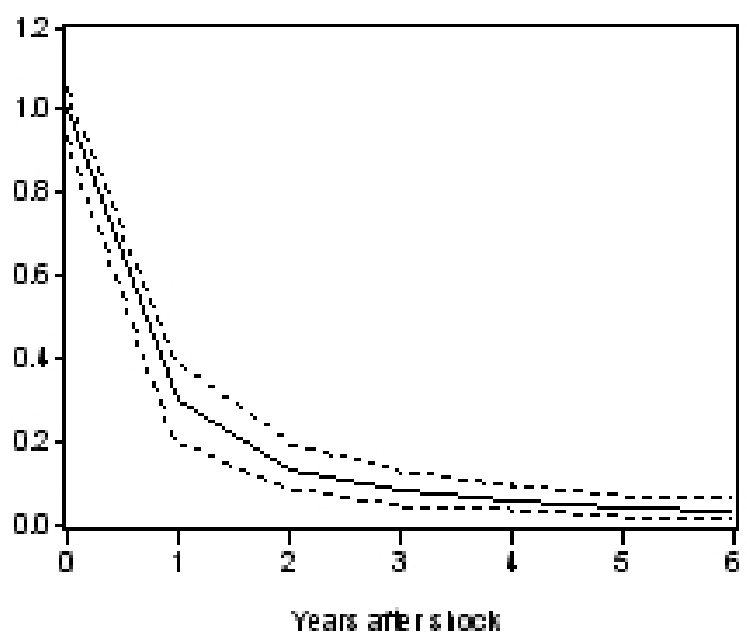

Response of price level

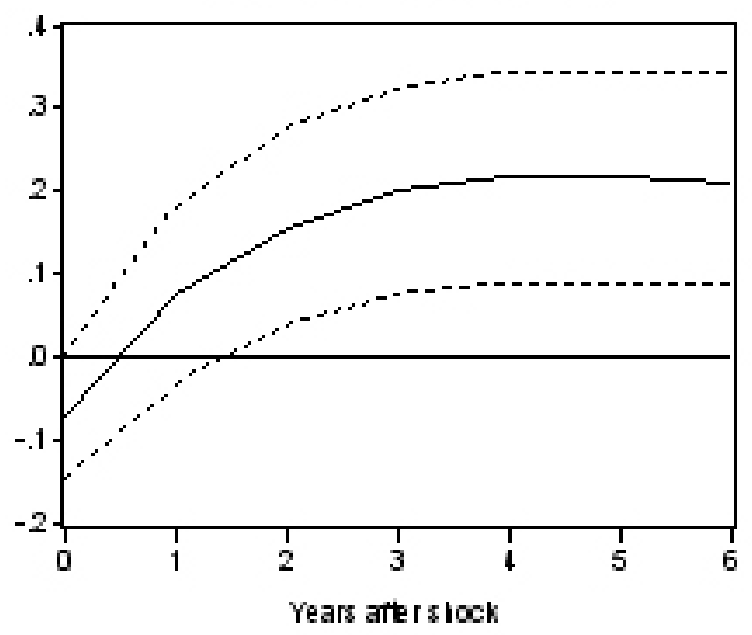

Response of private consumption

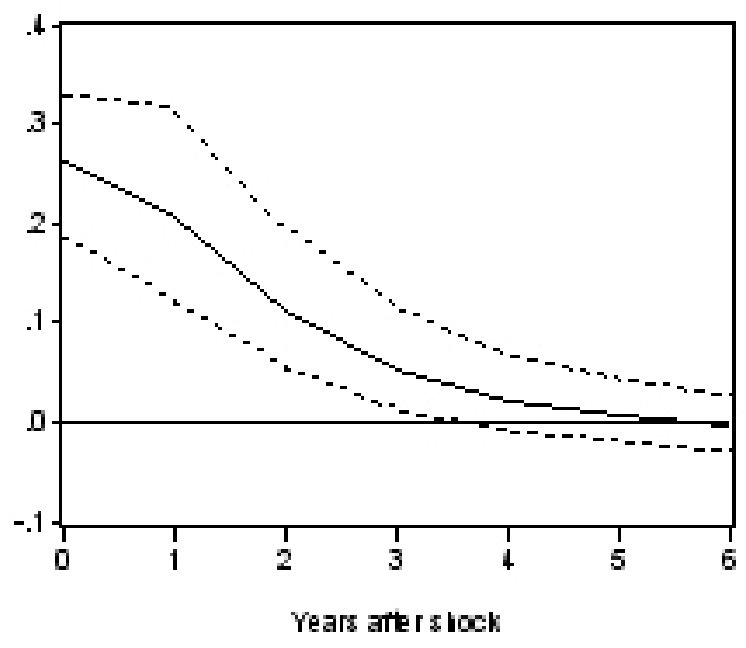

Response of private investmert

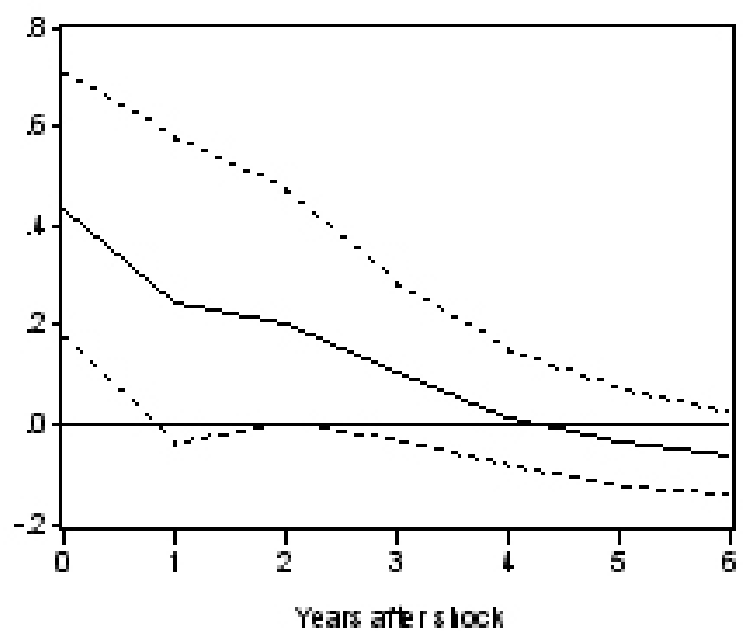

Response of net taxes

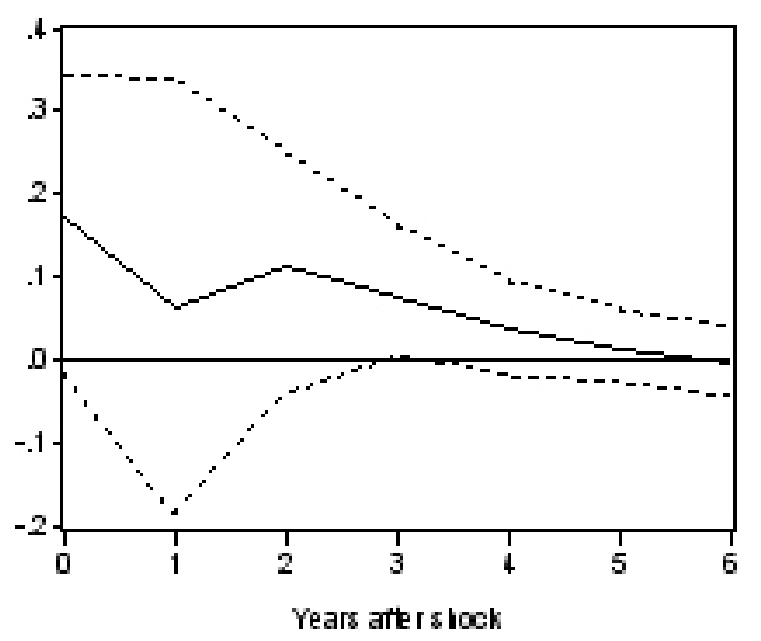


Fig.1: Wasteful Government Expenditure
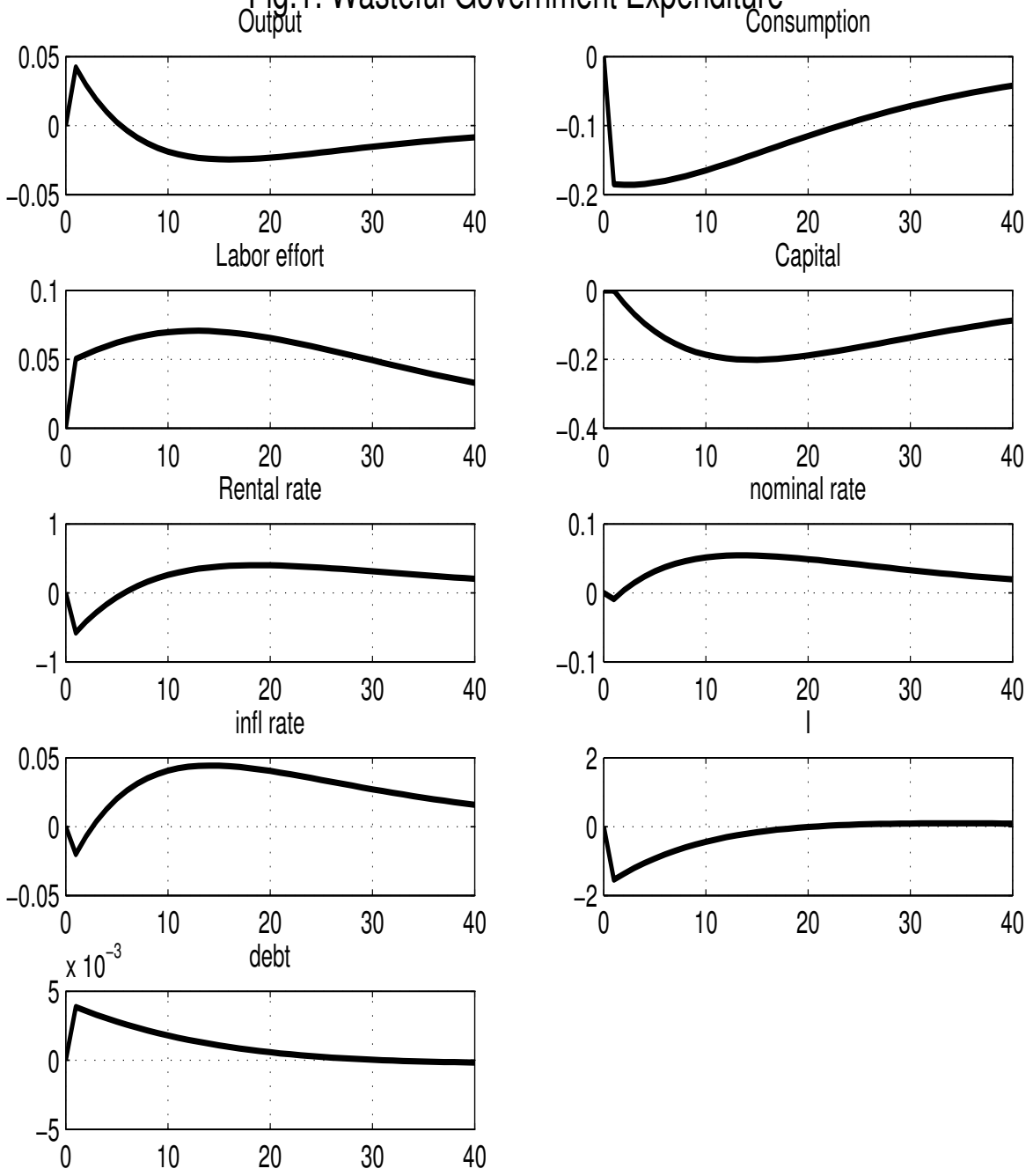

Figure 2: 
Fig.2: Edgeworth Complementarity

Output 2. Edyeworh Complementarity Consumption
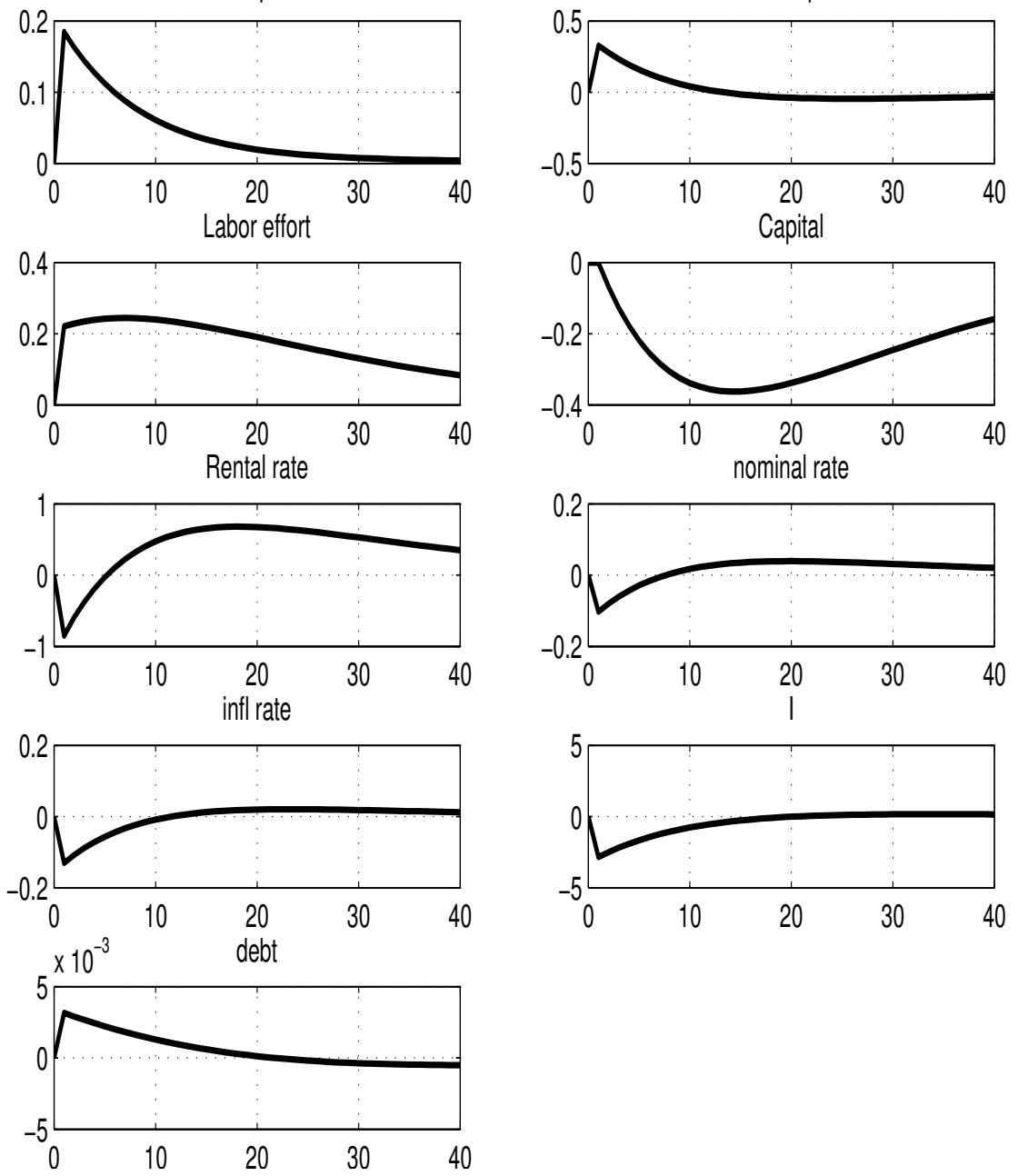

Figure 3: 
Fig.3: Edgeworth Substitutability Consumption
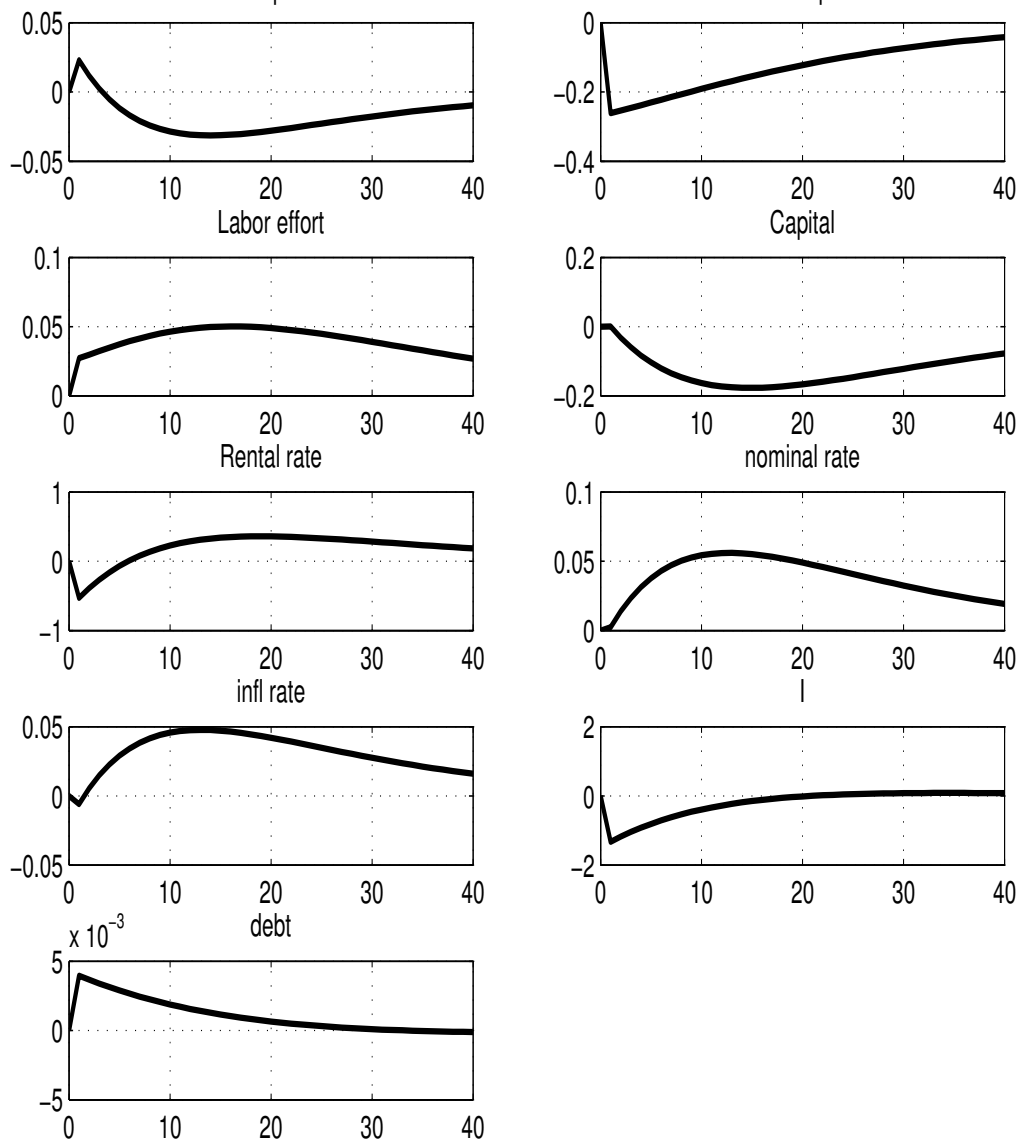

Figure 4: 


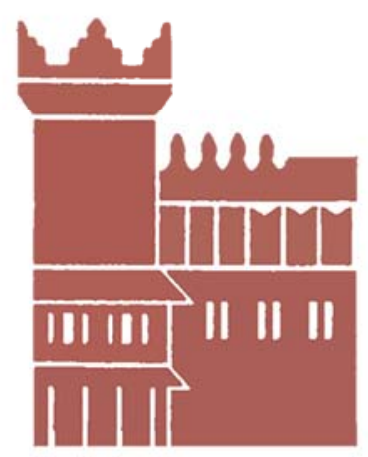

Alma Mater Studiorum - Università di Bologna DEPARTMENT OF ECONOMICS

Strada Maggiore 45

40125 Bologna - Italy

Tel. +39051 2092604

Fax +390512092664

http://www.dse.unibo.it 